\title{
Path Analysis: Psychososial and Economic Factors Affecting Diarrhea Incidence in Children Under Five in Jayapura, Papua
}

\author{
Tersia Marentiva Tungga'), Yulia Lanti Retno Dewi²), Bhisma Murti3) \\ 1)Masters Program in Public Health, UniversitasSebelasMaret \\ 2)Department of Perinatal, Hospital Dr. Moewardi, Surakarta \\ 3)Department of Public Health, Faculty of Medicine, UniversitasSebelasMaret
}

\begin{abstract}
Background: Diarrhea is a major cause of malnutrition and death in children under five. Studies have shown that there are some factors contributing to the incidence of diarrhea in infants. This study aimed to examine the psychososial and economic factors affecting diarrhea incidence in children under five in Jayapura, Papua.

Subjects and Method: This was an analytic observational study with a cross-sectional design. The study was conducted in North Jayapura Subdistrict, Papua, in February 2018. A sample of 200 children under five was selected for this study by fixed disease sampling, consisting of 100 children with diarrhea and 100 children without diarrhea. The dependent variable was diarrhea. The independent variables were maternal education, family income, exclusive breastfeeding, nutritional status, personal hygiene, and environmental sanitation. The data were collected by questionnaire. Path analysis was employed for data analysis in Stata 13.

Results: The risk of diarrhea increased with poor personal hygiene $(b=-1.04 ; 95 \% \mathrm{CI}=-1.75$ to $0.33 ; \mathrm{p}=0.004)$, poor environmental sanitation $(\mathrm{b}=-1.90 ; 95 \% \mathrm{CI}=-2.59$ to $-1.21 ; \mathrm{p}<0.001)$, poor nutritional status $(\mathrm{b}=-1.27 ; 95 \% \mathrm{CI}=-2.02$ to $-0.52 ; \mathrm{p}=0.001)$. The risk of diarrhea was indirectly affected by exclusive breastfeeding, maternal education, and family income.

Conclusion: The risk of diarrhea increases with poor personal hygiene, poor environmental sanitation, poor nutritional status, and indirectly affected by exclusive breastfeeding, maternal education, and family income.
\end{abstract}

Keywords: psychosocial factor, economic factor, diarrhea, children under five

\section{Correspondence:}

Tersia Marentiva Tungga. Masters Program in Public Health, Universitas Sebelas Maret, Jl. Ir. Sutami No. 36 A, Surakarta 57126, Central Java. Email: tersiatungga@gmail.com.

Mobile: +6285244754188 .

\section{BACKGROUND}

Diarrheal disease is the main cause of malnutrition and death in children under five. Globally, there were nearly 1.7 billion cases of diarrhea in children under five and killed about 525,000 children each year. Safe drinking water, adequate sanitation and proper treatment can prevent this disease. The growth of a child is also affected by the frequency of illness. Children who experience diarrhea will decrease the ability of nutrient absorption from the intestine and easy to lose weight. Children who have diarrhea for 15 days give twice the risk of malnutrition than healthy children (Jambro et al., 2012; Fekadu et al, 2015).

In the past, for most people, severe dehydration and lack of fluids are the main causes of diarrheal death. Now, other causes such as septic bacterial infections can also lead to an increase in the proportion of deaths related to diarrhea (World Health Organization, 2017).

The cases of diarrhea found in health facilities in Indonesia are approximately $6,897,463$, and for diarrhea cases handled 
Journal of Epidemiology and Public Health (2018), 3(3): 331-341

https://doi.org/10.26911/jepublichealth.2018.03.03.04

are about 2,544,084 (36.9\%). The prevalence of diarrhea in Indonesia is currently $3.5 \%$, while the incidence of diarrhea of children under five was $6.7 \%$. Diarrhea incidence of diarrhea is spread in the five highest provinces, namely Aceh 10.2\%, Papua 9.6\%, DKI Jakarta 8.9\%, South Sulawesi 8.1\% and Banten 8.0\%. Diarrhea treated at the health facility in Pa-pua Province was 85,034 with the number of diarrhea handled by 16,242 (19.1\%) (Basic Health Research, 2013, Ministry of Health, 2016).

The highest age group of childhood diarrhea occurs at 12-23 months, this is because early in life the baby is easy to experience various infectious diseases with immunological system conditions and intestinal conditions. Exclusive breastfeeding provides a protective effect against the occurrence of diarrhea because breast milk can meet the needs of the immunological system and naturally protects the body from digestive problems. It was found that infants who were not exclusively breastfed at 0-5 months had a 866-fold greater risk of diarrhea incidence and mortality than those who received exclusive breastfeeding (Sankar et al, 2015; Lamberti et al, 2011).

Based on preliminary study conducted by researchers, data were obtained from Jayapura City Health Office. It shows that the number of diarrhea in 2015 is 8080 people with the number of children under five years of 4.264 people (525). In 2016, the number of diarrhea was 9.521 people with the number of children with diarrhea of 4.143 people (43\%). The number of diarrhea cases of children under five from January to June 2017 is 2,523 people (49.8\%) spreading over five districts. The condition of Jayapura City which is the capital of Province shows that there are still many densely populated environments that pay little attention to the cleanliness of the environment, the diversity of drinking water sources used that have not been kept clean, there are still many under-five children with less nutritional status, mother's understanding of the importance of exclusive breastfeeding and personal hygiene, which is likely to cause diarrhea toddlers in Jayapura City.

Based on the description above, it shows that the incidence of diarrhea in some areas of Indonesia which is still high and an important issue for further action. It is expected that the path analysis approach can discover the influence of various factors so that it can be known that the variable has a higher influence on the incidence of diarrhea in infants.

\section{SUBJECTS AND METHOD \\ 1. Study Design \\ This was analytic observational study with a cross-sectional design. The study was con- ducted in Jayapura Utara district, Jaya- pura, Indonesia, in February 2018. \\ 2. Population and sample \\ The population in this study was mothers who have children under five. A sample of 200 children with their mother was select- ed for this study by fixed disease sampling.}

\section{Study variables}

The dependent variable was diarrhea. The independent variables were maternal education, family income, nutritional status, exclusive breastfeeding, environmental sanitation, and maternal personal hygiene.

\section{Operational definition of variables}

Maternal education was defined as a last formal education attained by mother. The measurement scale was categorical, but for the purpose of data analysis, it was transformed into dichotomous, coded o for $<$ Senior high school and 1 for $\geq$ Senior high school.

Family income was defined as income earned per month by parents either the father or the mother to fulfil the needs of 
the family. The measurement scale was continuous, but for the purpose of data analysis, it was transformed into dichotomous, coded o for low income $<$ minimum regional wage and 1 for $\geq$ minimum regional wage.

Exclusive breastfeeding was defined as breastfeeding for up to 6 months without any formula milk. The measurement scale was categorical, but for the purpose of data analysis, it was transformed into dichotomous, coded o for no and 1 for yes.

Nutritional status was defined as a body state that enhances the final outcome of the balance between nutrients entering the body and its utilitations, as measured by index based on body weight by age (WAZ). The measurement scale was continuous, but for the purpose of data analysis, it was transformed into dichotomous, coded $\mathrm{O}$ for wasting and 1 for normal weight.

Environmental sanitation was defined as the health status of an environment that includes housing, sewerage, water supply, and latrine availability. The measurement scale was continuous, but for the purpose of data analysis, it was transformed into dichotomous, coded 0 for poor and 1 for good.

Toddler diarrhea was defined as 0-59 months old children whose stool or feces turn into soft or liquid occurs at least three times a day within the last 3 months. The measurement scale was categorical, but for the purpose of data analysis, it was transformed into dichotomous, coded o for no and 1 for yes.

\section{Reliability test}

Based on the result of the total item correlation reliability test, it was found that the measurement of environmental sanitation and personal hygiene variables showed $\mathrm{r} \geq 0.20$ and Alpha Cronbach $\geq 0.70$, so that all the questions were declared as reliable.

\section{Data Analysis}

Analysis of univariate quantitative data was performed to display characteristic and descriptive data of research variables. Bivariate analysis to analyze the influence of the dependent variable on the independent variable using Chi-Square test. Path analysis to analyze the direct and indirect effects of dependent variables on the independent variables through intermediate variables.

\section{Research Ethics}

The research ethical clearance was obtained from the Research Ethics Committee at Dr. Moewardi Hospital, Surakarta, Central Java, Indonesia. Research ethics included issues such as informed consent, anonymity, confidentiality, and ethical clearance.

\section{RESULTS}

\section{Univariate analysis}

The characteristics of the study subjects were shown in Table 1

\begin{tabular}{|c|c|c|}
\hline Characteristics & $\mathbf{n}$ & $\%$ \\
\hline \multicolumn{3}{|l|}{ Age (Year) } \\
\hline$<24$ & 91 & $45 \cdot 5$ \\
\hline $\begin{array}{l}\geq 24 \\
\text { Occupation }\end{array}$ & 109 & $54 \cdot 5$ \\
\hline $\begin{array}{l}\text { Working outside } \\
\text { the house }\end{array}$ & 81 & 40.5 \\
\hline $\begin{array}{l}\text { Working at home } \\
\text { Children gender }\end{array}$ & 119 & 59.5 \\
\hline Male & 107 & $53 \cdot 5$ \\
\hline Female & 93 & 46.5 \\
\hline
\end{tabular}

Table 1 shows that most of mothers were over the age of 24 years (54.5\%), working at home (59.5\%). As many as $53.5 \%$ children were male (53.5\%).

Table 2 indicates that most of mothers were highly educated (71\%). As many as $64.5 \%$ children came from family with high family income. As many as $62 \%$ children received exclusive breastfeeding. 
Journal of Epidemiology and Public Health (2018), 3(3): 331-341

https://doi.org/10.26911/jepublichealth.2018.03.03.04

Based on the environmental sanitation variable, it can be concluded that most subjects had good environmental sanitation that is equal to 101 subjects or $50.5 \%$. Based on the individual hygiene variables, most of the subjects had good personal hygiene of 105 subjects or $52.2 \%$. Most of children did not experience diarrhea in the last 3 months (52\%).

\section{Bivariate Analysis}

Table 3 presents the results of bivariate analysis on the determinants of diarrhea in children under five. High maternal education $(\mathrm{OR}=0.14 ; 95 \% \mathrm{Cl}=0.07$ to 0.29 ; $\mathrm{p}<0.001)$, high family income $(\mathrm{OR}=0.31$; $95 \% \mathrm{CI}=0.17$ to $0.57 ; \mathrm{p}<0.001)$, exclusive breastfeeding $(\mathrm{OR}=0.29 ; 95 \% \mathrm{CI}=0.16$ to $0.54 ; \mathrm{p}<0.001)$, good nutritional status $(\mathrm{OR}=0.19 ; 95 \% \mathrm{CI}=0.10$ to $0.35 ; \mathrm{p}$ $<0.001$ ), and good environment sanitation $(\mathrm{OR}=0.1395 \% \mathrm{Cl}=0.07$ to $0.24 ; \mathrm{p}<0.001)$ reduced the risk of diarrhea.
Table 2. The results of univariate analysis

\begin{tabular}{|c|c|c|}
\hline Characteristics & $\mathbf{n}$ & $\%$ \\
\hline \multicolumn{3}{|l|}{ Education } \\
\hline$<$ Senior high school & 58 & 29 \\
\hline$\geq$ Senior high school & 142 & 71 \\
\hline \multicolumn{3}{|l|}{ Family Income } \\
\hline$<$ Minimum wage & 71 & $35 \cdot 5$ \\
\hline$\geq$ Minimum wage & 129 & 64.5 \\
\hline \multicolumn{3}{|l|}{ Exclusive } \\
\hline \multicolumn{3}{|l|}{ Breastfeeding } \\
\hline Not exclusive & 68 & 34 \\
\hline breastfeeding & 132 & 66 \\
\hline \multicolumn{3}{|l|}{ Exclusive breastfeeding } \\
\hline \multicolumn{3}{|l|}{ Nutritional Status } \\
\hline Poor & 76 & 38 \\
\hline Good & 124 & 62 \\
\hline \multicolumn{3}{|l|}{ Environmental } \\
\hline \multicolumn{3}{|l|}{ Sanitation } \\
\hline Poor & 99 & 49.5 \\
\hline Good & 101 & 50.5 \\
\hline \multicolumn{3}{|l|}{ Individual hygiene } \\
\hline Poor & 95 & $47 \cdot 5$ \\
\hline Good & 105 & 52.2 \\
\hline \multicolumn{3}{|l|}{ Diarrhea } \\
\hline Not diarrhea & 104 & 52 \\
\hline Dhiarrea & 96 & 48 \\
\hline
\end{tabular}

Table 3. The results of bivariate analysis on the $d$ determinan yang mempengaruhi diare balita

\begin{tabular}{|c|c|c|c|c|c|c|c|}
\hline \multirow{3}{*}{ Variable } & \multicolumn{4}{|c|}{ Diarrhea in children under five } & \multirow{3}{*}{ OR } & \multirow{3}{*}{$95 \% \mathrm{Cl}$} & \multirow{3}{*}{$\mathbf{p}$} \\
\hline & \multicolumn{2}{|c|}{ Not diarrhea } & \multicolumn{2}{|c|}{ Diarrhea } & & & \\
\hline & $\mathbf{n}$ & $\%$ & $\mathbf{n}$ & $\%$ & & & \\
\hline \multicolumn{8}{|l|}{ Age } \\
\hline$<$ Senior high school & 12 & 20.7 & 46 & 79.3 & \multirow[t]{2}{*}{0.14} & $0.07-$ & \multirow[b]{2}{*}{$<0.001$} \\
\hline$\geq$ Senior high school & 92 & 64.6 & 50 & 35.2 & & 0.29 & \\
\hline \multicolumn{8}{|l|}{ Family Income } \\
\hline$<$ Minimum wage & 24 & 33.8 & 47 & 66.2 & \multirow[t]{2}{*}{0.31} & $0.17-$ & \multirow[t]{2}{*}{$<0.001$} \\
\hline$\geq$ Minimum wage & 80 & 62 & 49 & 38 & & 0.57 & \\
\hline \multicolumn{8}{|c|}{ Exclusive Brastfeeding } \\
\hline No breastfeeding & 22 & 32.4 & 46 & 67.6 & \multirow[t]{2}{*}{0.29} & $0.16-$ & \multirow[t]{2}{*}{$<0.001$} \\
\hline Breastfeeding & 82 & 62.1 & 50 & 37.9 & & 0.54 & \\
\hline \multicolumn{8}{|l|}{ Nutritional Status } \\
\hline Poor & 21 & 27.6 & 55 & 72.4 & \multirow[t]{2}{*}{0.19} & $0.10-$ & \multirow[t]{2}{*}{$<0.001$} \\
\hline Good & 83 & 66.9 & 41 & 33.1 & & 0.35 & \\
\hline \multicolumn{8}{|c|}{ Environment Sanitation } \\
\hline Poor & 28 & 28.3 & 71 & 71.7 & \multirow[t]{2}{*}{0.13} & $0.07-$ & \multirow[t]{2}{*}{$<0.001$} \\
\hline Good & 76 & 75.2 & 25 & 24.8 & & 0.24 & \\
\hline Individual Hygiene & & & & & \multirow{3}{*}{0.19} & & \multirow[t]{3}{*}{$<0.001$} \\
\hline Poor & 30 & 31.6 & 65 & 68.4 & & $0.11-$ & \\
\hline Good & 74 & 70.5 & 31 & 29.5 & & 0.35 & \\
\hline
\end{tabular}




\section{Path Analysis}

From Figure 1, it can be seen that there was a personal hygiene relationship with diarrhea incidence in children under five. Good personal hygiene reduced the risk of diarrhea and it was statistically significant $(\mathrm{b}=-1.04 ; 95 \% \mathrm{Cl}=-1.75$ to $-0.33 ; \mathrm{p}=$ $0.004)$.

There was a relationship between environmental sanitation with the incidence of diarrhea in children under five. Good environmental sanitation reduced the risk of diarrhea in children under five and it was statictically significant $(b=-1.90 ; 95 \% \mathrm{Cl}=-$ 2.59 to $-1.21 ; \mathrm{p}<0.001)$.

There was a relationship between children nutritional status with the incidence of diarrhea in children under five. Good nutritional status reduced the risk of diarrhea in children under five $(b=-1.27$; $95 \% \mathrm{Cl}=-2.02$ to $0.52 ; \mathrm{p}=0.001$ ).

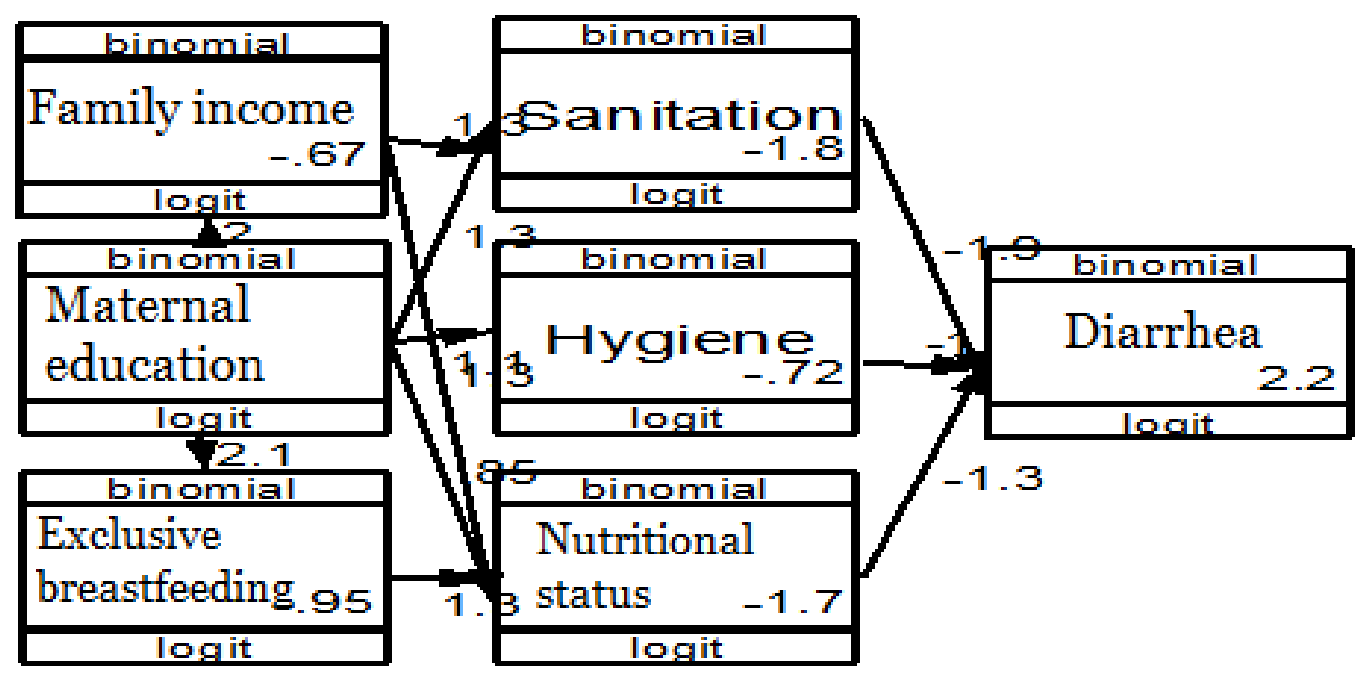

Figure 1. Structural model of path analysis

There was a relationship between maternal education and maternal personal hygiene. High maternal education improved personal hygiene $(b=1.15 ; 95 \% \mathrm{CI}=$ 0.50 to 1.79 ; $\mathrm{p}<0.001$ ).

There was a relationship between maternal education and environmental sanitation. Maternal education improved environmental sanitation $(b=1.28 ; 95 \%$ $\mathrm{CI}=0.52$ to $2.03 ; \mathrm{p}=0.001$ ).

There was a relationship between family income and environmental sanitation. High family income improved environmental sanitation $(b=1.27 ; 95 \% \mathrm{Cl}=$ 0.58 to $1.96 ; \mathrm{p}<0.001)$.

There was a relationship between maternal education and family income. High maternal education improved family income $(b=1.95 ; 95 \% \mathrm{Cl}=1.28$ to $2.63 ; \mathrm{p}=$ $<0.001)$.

There was a relationship between maternal education and children's nutritional status. High maternal education improved nutritional status in children under five $(b=0.85 ; 95 \% \mathrm{Cl}=0.06$ to $1.63 ; \mathrm{p}=$ 0.034).

There was a relationship between family income and children's nutritional status. High family income improved children's nutritional $(b=1.26 ; 95 \% \mathrm{Cl}=$ 0.53 to $1.98 ; \mathrm{p}=0.001$ ).

There was a relationship between exclusive breastfeeding and children nutritional status. Children who get exclusive breastfeeding increased children nutritional 
Journal of Epidemiology and Public Health (2018), 3(3): 331-341

https://doi.org/10.26911/jepublichealth.2018.03.03.04

status $(\mathrm{b}=1.28 ; 95 \% \mathrm{Cl}=0.54$ to $2.02 ; \mathrm{p}=$ 0.001).

There was a relationship between maternal education and exclusive breast- feeding. High maternal education increased the likelihood of exclusive breastfeeding $(\mathrm{b}=2.08 ; 95 \% \mathrm{CI}=1.40$ to 2.76 ; $\mathrm{p}<0.001$.

Table 4. The results of path analysis on the psychososial and economic factors affecting diarrhea incidence in children under five

\begin{tabular}{|c|c|c|c|c|c|c|}
\hline \multirow{2}{*}{$\begin{array}{c}\text { Dependent } \\
\text { Variable }\end{array}$} & & \multirow[b]{2}{*}{ Independent Variable } & \multirow[b]{2}{*}{ b } & \multicolumn{2}{|c|}{ Cl 95\% } & \multirow[b]{2}{*}{$\mathbf{p}$} \\
\hline & & & & $\begin{array}{c}\text { Lower } \\
\text { Limit }\end{array}$ & $\begin{array}{l}\text { Upper } \\
\text { Limit }\end{array}$ & \\
\hline \multicolumn{7}{|l|}{ Direct Effect } \\
\hline Diarrhea in & $\leftarrow$ & Good personal hygiene & -1.04 & -1.75 & -0.33 & 0.004 \\
\hline children under five & $\leftarrow$ & Good environment sanitation & -1.90 & -2.59 & -1.21 & $<0.001$ \\
\hline \multicolumn{7}{|l|}{ Indirect Effect } \\
\hline $\begin{array}{l}\text { Good personal } \\
\text { hygiene }\end{array}$ & $\leftarrow$ & $\begin{array}{l}\text { Education } \geq \text { Senior high } \\
\text { school }\end{array}$ & 1.15 & 0.50 & 1.79 & $<0.001$ \\
\hline $\begin{array}{l}\text { Good } \\
\text { environmental }\end{array}$ & $\leftarrow$ & $\begin{array}{l}\text { Education } \geq \text { Senior high } \\
\text { school }\end{array}$ & 1.28 & 0.52 & 2.03 & 0.001 \\
\hline sanitation & $\leftarrow$ & High family income & 1.27 & 0.58 & 1.96 & $<0.001$ \\
\hline $\begin{array}{l}\text { High family } \\
\text { income }\end{array}$ & $\leftarrow$ & $\begin{array}{l}\text { Education } \geq \text { Senior high } \\
\text { school }\end{array}$ & 1.95 & 1.28 & 2.63 & $<0.001$ \\
\hline \multirow{3}{*}{$\begin{array}{l}\text { Good nutritional } \\
\text { status }\end{array}$} & $\leftarrow$ & $\begin{array}{l}\text { Education } \geq \text { Senior high } \\
\text { school }\end{array}$ & 0.85 & 0.06 & 1.63 & 0.034 \\
\hline & $\leftarrow$ & High family income & 1.26 & 0.53 & 1.98 & 0.001 \\
\hline & $\leftarrow$ & Exclusive breastfeeding & 1.28 & 0.54 & 2.02 & 0.001 \\
\hline $\begin{array}{l}\text { Exclusive } \\
\text { breastfeeding } \\
\text { Observation Score } \\
\text { Log likelihood }=-8\end{array}$ & $\leftarrow$ & $\begin{array}{l}\text { Education } \geq \text { Senior high } \\
\text { school }\end{array}$ & 2.08 & 1.40 & 2.76 & $<0.001$ \\
\hline
\end{tabular}

\section{DISCUSSIONS}

\section{The effect of maternal education on diarrhea incidence in toddlers}

Based on the result of path analysis in this study, it was showed that there was an indirect effect between maternal education and diarrhea incidence in toddlers. The result of analysis showed that there was a relationship between maternal education and the incidence of diarrhea in toddlers through family income and environmental sanitationwhich was statistically significant. The result of analysis also showed that there was a significant relationship between maternal education and diarrhea incidence in toddlers through exclusive breastfeeding and nutritional status. The result of analysis also showed that education may affect the incident of diarrhea in toddlers through environmental sanitation, personal hygiene, and nutritional status.

The result of this study ins consistent with a study by Mihrete et al. (2014), which stated that maternal education was associated with diarrhea in children under five. It was because education level may determine maternal knowledge about health. The result of this study was also consistent with Desta et al. (2017), which stated that high maternal education affected children nutritional status, personal hygiene, proper feeding time, and infectious disease, including diarrheal diseases.

Education may increase the awareness about transmission and prevention of diarrhea and may encourage healthy beha- 
vior change at the household level (Woldu, 2016). Mothers with a high education level and adequate income would also have a house with health facilities and environmental sanitation and serving healthy foods (Wobudeya et al., 2011).

\section{The effect of family income on diarrhea incidence in children under five}

Based on the result of path analysis in this study showed that there was an indirect effect between family income and diarrhea incidence in children under five through environment sanitation and nutritional status.

The result of this study is consistent with a study by Oliveira et al. (2017), which stated that family income was associated with the incidence of diarrhea. Lower family income, the lower the maternal selfefficacy prevent diarrhea in children under five.

Family with high family income usually used soap to wash their hands, used clean water facilities, and have family toilets at home, while families with low income were more susceptible to diarrhea because they cannot afford such facilities. The result of this study is also supported by a study by Randon et al. (2015), which stated that family income was an important determinants of health.

Economic inequality would affect diarrhea in toddlers, parents who have high incomes would be easier to fulfill all the needs of the family, on the other hand, parents who have low income would tend to be more difficult to fulfill the needs of the family and eventually, it would give an impact on family's health.

The result of this study was also supported by a study done by Avachat et al. (2011), which stated that there was a positive relationship between family income and diarrhea in toddlers through children nutritional status. According to Woldu (2016), children with low income family have a higher chance of experiencing diarrhea compared to chidlrem with highincome family. This fact proved that high income families have a greater chance to use soap to wash their hands and clean mineral water to protect microbial contamination in water, and they were capable to build better toilets. Low income families were suffering from diarrhea because they cannot fulfill the facilities above.

\section{The effect of exclusive breastfeed- ing on diarrhea incidence in child- ren under five}

Based on the result of path analysis in this study, there was an indirect effect between exclusive breastfeeding and diarrhea in children under five through nutritional status.

The result of this study was supported by a study done by Bener et al. (2011) which stated that there was a significant relationship between exclusive breastfeeding and the incidence of diarrhea. The result of this study showed that 0-3 years old children who have been given exclusive breastfeeding were less likely to experience diarrhea, compared to children who did not get exclusive breastfeeding. The result of this study was supported by a study by Gizaw et al. (2017), which stated thatchildren who did not receive exclusive breastfeeding within the first six months had a greater chance of experiencing diarrhea. This was because the supplementary foods may increase the risk of children to expose to various types of disease caused by pathogenic microorganisms derived from water contaminated with disease. The result of this study was in accordance with a study done by Iskandar et al. (2015) which stated thatbreast milk has all the elements that fulfill the nutritional needs of infants over a period of about 6 months, unless the 
Journal of Epidemiology and Public Health (2018), 3(3): 331-341

https://doi.org/10.26911/jepublichealth.2018.03.03.04

mother experienced severe less nutrition or other health problems. Nutritional status was a very important aspect for children, and nutritional status played a role in a child's immunity. Malnourished children can caused various diseases, such as diarrhea. Diarrhea and malnutrition have a close association because infections can reduce nutritional status, this was due to decreased food intake, malabsorption, and the enhancement of body catabolism.

Breast milk was hygienic, inexpensive, easy to administer, and was available to babies. Colostrum contained 10-17 times more immune substances than formula milk. Immunity contained in breast milk would protect children from diarrhea and other infectious diseases (Ministry of Health, 2014).

\section{The effect of nutritional status on diarrhea incidence in in children under five}

Based on the result of path analysis in this study, it was showed that there was a direct effect between nutritional status and diarrhea incidence in toddlers. This was because children nutritional status was related to their immune power or immune system. Children who have poor nutritional status were more susceptible to diarrhea compared to children who have good nutritional status because children who have good nutritional status have a better and stronger immune system.

According to Iskandar et al. (2015), nutritional status was important for children, and nutritional status played a role in a child's immunity. Malnourished children can cause various diseases, such as diarrhea.

\section{The effect of personal hygiene on diarrhea incidence in toddlers}

Based on the result of path analysis in this study, there was a direct effect between personal hygiene and diarrhea in children under five. Personal hygiene was associated with the prevention of infectious diseases such as diarrhea, the cleaner the mother in maintaining her personal hygiene as well as the foods given to her toddler, then the food would be more healthy and not contaminated by the source of infectious disease. Mothers who were used to maintain personal hygiene and their children's foods would be giving more attention to the condition of their body, so the mothers would wash their hands first before feeding their toddlers. Washing the hands was an effective way to prevent the transmission of diseases. Mothers who maintained personal hygiene would also cut and cleaned their nails, therefore, the diseases did not stick inside the nail.

The result of this study was supported by a study done by Sulistiyowati and Lestari (2017), which stated that maternal behavior to maintain food hygiene has an effect on the incidence of diarrhea. The results of this study also stated that the better the maternal behavior to maintain food hygiene, then the babies would be less likely to experience diarrhea. The result of this study was in accordance with a study done by Ferllando and Asfani (2015), which stated that there was a relationship between personal hygiene and the incidence of diarrhea. Hand hygiene should be a priority because dirty or contaminated hands can transfer bacteria or pathogenic viruses from the body, feces or other sources to food. Mothers who did not wash their hands after defecate and rarely cut their nails can trigger the occurrence of diarrhea.

Personal hygiene was an effort made by individuals to maintain personal hygiene in avoiding the diseases. Personal hygiene need to be applied to the individuals and family to avoid the disease and to maintain the productivity of ourselves (Sender, 2005). 


\section{The effect of environmental sanita- tion on diarrhea incidence in children under five}

Based on the result of path analysis in this study, there was a direct effect between environmental sanitation and diarrhea in children under five. Poor environmental sanitation would be bad for health. Various types of diseases would arise because of poor environmental sanitation, as well as not maintaining the sanitation of drinking water so that drinking water contaminated by the disease, especially diarrhea diseases, did not have a clean toilet or even defecate carelessly so that the surrounding environment becomes polluted. The contaminated environment can be a place for disease that would be carried by vectors of diseases transmission such as flies that eventually settle on drinks or food to be eaten, and it triggered the incidence of diarrhea in toddlers. Having a non-enclosed bin can also trigger the occurrence of diarrhea in toddlers, because the waste was one of the places of disease that was easily infested by vectors of diseases transmission such as flies.

The result of this study was supported by a study done by Putra et al. (2017), which showed that environmental sanitation was associated with the incidence of diarrhea in children, this was because children who did not live in places that have clean water facilities, qualified bathroom conditions, and appropriate waste disposal were at higher risk of diarrhea. The prevention of diarrheal diseases can be done by ensuring that clean water was taken from uncontaminated sources and placed the water in a clean and closed container. Uncovered toilet facilities would be reachable by the vector that caused diarrheal diseases that can contaminate food and drink.

Hygiene and sanitation conditions in the household were the risk factors for diarrhea. Unhealthy environments such as the environment that has contaminated by the diarrhea disease then accumulated with unhealthy behavior in giving food and drink can caused diarrhea (Oroluntoba et al., 2014). Home environmental factors that can cause diarrhea include the availability or unavailability of Clean Water Facilities (CWF), toilet, Waste water Disposal Channels (WDC), home conditions, trash can, and density. Children who live in houses that did not have their own toilet facilities were more susceptible to diarrhea than toddlers who have their own toilet facilities (Mihret et al., 2014).

\section{REFERENCES}

$\overline{\text { Avachat SS, Phalke VD, Phalke DB, Aarif }}$ SM, Kalakoti P (2011). A cross-sectional study of socio-demographic determinants of recurrent diarrhoea among childrenunderfive of rural area of Western Maharashtra, India.Australas Med J. 4(2):72-5. doi: 10.4066/AMJ.2011.524.

Bener A, Ehlayel MS, Abdulrahman HM (2011). Exclusive Breast Feeding and Prevention of Diarrheal Diseases: A Sttudy in Qatar. Qatar: Hamad Medical Corporation. http://www.scielo.br/scielo.php?script=sci_arttex t\&pid=S1519-38292011000100009. 11(1): 83-87.

Desta KB, Assimamaw TN, Ashenafi DT. (2017). Knowledge, Practice, and Associated Factors of Home-Based Management of Diarrhea among Caregivers of Children Attending Under-Five Clinic in Fagita Lekoma District, Awi Zone, Amhara Regional State, Northwest Ethiopia, 2016. Nurs Res Pract: 8084548. doi: 10.1155/$2017 / 8084548$. 
Journal of Epidemiology and Public Health (2018), 3(3): 331-341

https://doi.org/10.26911/jepublichealth.2018.03.03.04

Dinkes Kota Jayapura (2016). Laporan Tahunan Data Kesakitan (LB1) Tahun 2015. (2017). Laporan Tahunan Data Kesakitan (LB1) Tahun 2016. (2017). Laporan Bulanan Data Kesakitan (LB1) bulan Januari sampai Juni 2017.

Fekadu Y, Mesfin A, Haile D, Stoecker BJ. (2015). Factors associated with nutritional status of infants and young children in Somali Region, Ethiopia: a cross-sectional study. BMC Public Health. doi: 10.1186/s12889-015-2190-7.

Ferllando HT, Asfawi S (2015). Hubungan antara Sanitasi Lingkungan dan Personal Hygiene Ibu dengan Kejadian Diare Pada Balita di Wilayah Kerja Puskesmas Mangkang. https://publikasi.dinus.ac.id/index.php/visikes/art icle/view/1198. Jurnal VISIKES. 14(2): 131-138. ISSN: 1412-3746.

Gizaw Z, Woldu W, Bitew BD (2017). Child Feeding Practices and Diarrheal Disease Among Children Less Than Two Years of Age of The Nomadic People in Hadaleala District, Afar Region, Northeast Ethiopia. Int Breastfeed J. doi: 10.1186/s13006-017-0115-z.

Iskandar WJ, Sukardi W, Soenarto Y (2015). Risk of nutritional status on diarrhea among under five children. Paediatrica Indonesia. 55 (4): 237238.

Jamro B, Junero AA, Lal S, Bouk RR, Jamro S (2012). Risk Factors for Severe Acute Malnutrition in Children under the Age of Five Year in Sukkur. Pak J Med Res. Vol 51:4.

Kementerian Kesehatan. (2016). Profil Kesehatan Indonesia Tahun 2016. Jakarta: Kemenkes.

Lamberti LM, Walker CLF, Noiman A, Victoria C, Black R (2011). Breast- feeding and the risk for diarrhea morbidity.BMC Public Health.11 (3).

Mihrete TS, Alemie GA, Teferra AS.(2014). Determinants of childhood diarrhea among underfive children in BenishangulGumuz Regional State, North West Ethiopia.BMC Pediatrics. 14:102 http://www.biomedcentral.com/14712431/14/102.

Murti B (2013). Desain dan Ukuran Sampel untuk Penelitian Kuantitatif dan Kualitatif di Bidang Kesehatan. Yogyakarta: Gajah Mada University Press. (2016). Prinsip dan Metode Riset Epidemiologi. Surakarta: Universitas Sebelas Maret.

Oliveira RKLD, Oliveira BSBD, Bezerra, JC, Silva MJND, Melo FMDS, Joventino, ES. 2017. Influence of Socio Economic Condoitions and Maternal Knowledge in Self-Effectiveness for Prevention of Childhood Diarrhea. Esc Anna Nery. 21(4): e20160361.

Oloruntoba EO, Folarin TB, Ayede AI (2014). Hygiene and sanitation risk factors of diarrhoeal disease among under-five children in Ibadan, Nigeria. PMC.14(4): 1001-1011. DOI: 10.4314/ahs.v14i4.32.

Putra ADP, Rahardjo M, Joko T (2017). Hubungan Sanitasi Dasar dan Personal Hygiene dengan Kejadian Diare pada Balita di Wilayah Kerja Puskesmas Tasikmadu Kabupaten Karanganyar. Jurnal Kesehatan Masyarakat. 5(1). ISSN: 236-3346.

Rondon AMP, Ardila CZ, Martínez AH, Sternberg AMR, Meerbeke AVV. (2015). Country characteristics and acute diarrhea in children from developing nations: a multilevel study. BMC Public Health. 15:811. doi: 10.1186/s12889-015-2120-8.

Sander MA (2005). Hubungan faktor Sosio Budaya dengan Kejadian Diare di 
Desa Candinegoro Kacamatan Wonoayu Sidoarjo. Medika. 2(2): 163-171.

Sankar MJ, Sinha B, Chowdhury R, Bhandari R, Taneja S, Martines J, Bahl R (2015). Optimal breastfeeding practices and infant and child mortality: a systematic review and metaanalysis. Acta Paediatrica. DOI: 10.1111/apa.13147.

Sulistiyowati T, Lestari RH. Perilaku Ibu tentang Hygiene Makanan dengan Kejadian Diare Pada Balita di Desa Bareng Jombang. http://jurnal.ibijabar.org/wp-content/uploads/2017/o9/1TUTUT-RINI-jombang.pdf.

Midwife journal. 3(2). ISSN 24773441.

Wobudeya E, Bachou H, Karamagi CK, Kalyango JN, Mutebi E, Wamani H
(2011). Breastfeeding and Risk of Rotavirus Diarrhea in Hospitalized Infants in Uganda: a Matched Case Control Study. BMC Pediatrics. 11-17.

Woldu W, Bitew BD, Gizaw A (2016). Socioeconomic factors associated with diarrheal diseases among under-five children of the nomadic population in northeast Ethiopia Tropical Medicine and Health 44:40 DOI 0.1186/s4118206-0040-7.

World Health Organization (WHO). (2017). Diarrhoeal Disease.http://www.who.int/mediacentre/factsheets/fs330/en/.Prevalence of undernutrition and associated factors among children aged between six to fifty nine months in BuleHora district, South Ethiopia. 